\section{Strange Attraction}

Each year, several million tóns of metal are produced for use as magnetic materials in many everyday devices and processes common to all of us - from radio communication, information storage, telephone receivers, and stereo speakers to electric motors, transformers, and generators. All these things would have completely baffled the shepherd Magnes 2500 years ago when, according to legend, he stepped on a lodestone (magnetite). Pliny the Elder wrote of Magnes, "the nails of whose shoes and the [iron] tip of whose staff stuck fast in a magnetick field while he pastured his flocks."

The Roman philosopher and poet Lucretius, writing in the first century B.C., ascribed the name "magnet" to the Greek province of Magnesia in Thessaly, where magnetite was first mined. In 500 B.C. Thales of Miletius related that magnetite would pick up small pieces of iron and other bits of magnetite. According to Plato, Socrates claimed that a large enough lodestone could support by magnetic attraction a chain made of iron rings.

Magnetite, or lodestone, is a natural magnetic oxide of iron $\left(\mathrm{Fe}_{3} \mathrm{O}_{4}\right)$, a black opaque mineral of the spinel group with a metallic luster. Today, magnetite is found in commercial quantities in Norway, Sweden, the Ural Mountains, and in some parts of the United States.

The ancients seemed to view magnetite as a plaything and a curiosity. Lucretius mentioned that "sometimes, too, iron draws back from this stone, for it is wont to flee from and follow it in turn." To explain this phenomena, some of the ancients proposed that the surface of a magnet was covered with tiny hooks, while pieces of iron were covered with little rings to catch the hooks. Other philosophers claimed that magnetite emitted particles, leaving an empty place around the stone into which a piece of iron could move.

The term lodestone means "leading stone," which refers to its ability to be used as a compass. The ancient Greeks do not appear to have known of the compass, but some writers suggest that the Chinese had been using compasses for land travel as early as the 26 th century B.C. The Englishman Alexander Neckam (1157-1217) gives the first known European reference to a compass, and in 1269 the French crusader
Petrus Peregrinus de Maricourt (Peter the Pilgrim) described in detail the use of a compass for navigation. He believed that the lodestone derived its power from the sky. Apparently on one of his long voyages, Peter the Pilgrim played with a sphere of magnetite, exploring its surface with bits of iron. He discovered that lines of magnetic force circled the sphere and seemed to intersect at two opposite places on the globe, which he named "poles" in analogy to the Earth's poles. It wasn't until more than three centuries later in 1600 , though, that William Gilbert, physician to Queen Elizabeth I, proposed that the Earth itself was a magnet.

Gilbert summarized his awe of magnetism by writing: "Magnetick force is animate, or imitates life; and in many things surpasses human life, [which] is bound up in the organic body." Gilbert also discovered that magnetite lost its magnetic properties when heated to a bright red, but regained them when it cooled.

Magnetite was the only naturally occurring magnetic material known to early philosophers. But by the end of the 19th century all the known elements and many compounds had been tested for magnetism. Pierre Curie undertook the first extended systematic investigation of the magnetic properties of elements. He found that all matter was to some extent magnetic, but that the elements fell into three distinct categories. Only iron, cobalt, and nickel were found to have significant magnetic properties, and Curie called these "ferromagnetic" materials. (In 1935 gadolinium was also shown to be ferromagnetic, and in the 1960s researchers found that five other rare-earth elements become ferromagnetic only at low temperatures.) Other elements had very weak magnetic properties, and Curie labeled these "paramagnetic" substances. Most common, though, were the "diamagnetic" materials, which are slightly repelled by magnetic force.

Of the three ferromagnetic metals, industrial magnetic applications extensively use only iron in its elemental form. However, the creation of some alloys greatly improved their magnetic characteristics for a wide range of applications. The earliest alloy to be made into a permanent magnet was carbon steel, which was heated to about $800^{\circ} \mathrm{C}$ and then quenched to freeze in the necessary hardness and magnetic traits (such as improved retentivity and coercivity). After 1855 it was known that adding tungsten or manganese improved carbon steel as a permanent magnet.

Many different families of magnetic alloys have come into use since the beginning of this century. At the turn of the 20th century Sir Robert Hadfield invented iron-silicon alloys, which have especially high permeabilities in the orientation in which the alloy passes through the rolling press. Chrome-steel alloys were developed in 1917, and until 1930 the only commercially available permanent magnets were made of carbon-steel, chrome-steel, or tungstensteel. In 1931 the Japanese developed cobalt-steel alloys which had improved coercivities over other alloys. Alnico magnets came into use in the 1940s, resulting from research by the General Electric Company. These magnets were hard and brittle and could be machined only by wet grinding. They proved, however, to have high residual flux densities, high energy products, and high coercivities.

Although nickel is a ferromagnetic substance, pure nickel itself is a relatively poor magnetic material. The addition of iron increases its magnetic permeability, and iron-nickel alloys, or permalloys, resulted in 1920 from the work of G.W. Elmen. During World War II, permalloys began to be heattreated in an environment of pure hydrogen at $1200-1300^{\circ} \mathrm{C}$, which gave the alloy extremely high permeabilities. After 1955 thin permalloy films were used for new applications, such as early computer technology.

The magnetic properties of rare-earth elements were extensively investigated in the 1960 s due to the increased availabilities of such elements and the greater ability to work with low temperatures in the laboratory (because liquid helium became easier to obtain).

Humans have indeed used magnetic materials in many applications. In the mid-1970s, however, scientists discovered the presence of magnetite inside some bacteria that have a sense of direction and can line themselves up to the Earth's magnetic field. Magnetite has also been found in the tissue of higher animals known to have an acute sense of direction, such as honey bees and homing pigeons. We aren't the only living things to put magnetic materials to work for us.

KEVIN J. ANDERSON 


\section{Announcement and Call for Papers}

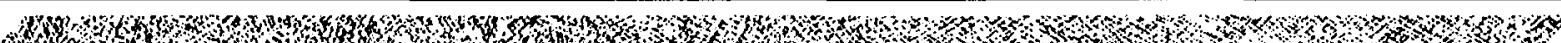

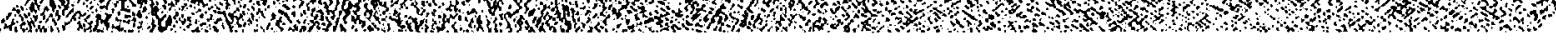

Research in Nondestructive Evaluation

A Journal of the American Society for Nondestructive Testing

\section{Editor-in-Cbief:}

\section{H. Thomas Yolken,}

National Bureau of Standards B344 Materials Bldg.

Gaithersburg, MD 20899 USA

\section{Editorial Board:}

J.D. Achenbach, Northwestern University, USA

\section{G. Birnbaum,}

National Bureau of Standards, USA

J. Bussière,

National Research Council, Canada

W. Ellingson,

Argonne National Laboratory, USA

R.E. Green, Jr.,

The Johns Hopkins University, USA

P.J. Hoeller,

Fraunhofer Institüt für Zerstorungsfreie Prufverfahren, West Germany

\section{A.E. Holt,}

Southwest Research Institute, USA

T. Kishi,

University of Tokyo, Japan

R. W. McClung,

Oak Ridge National Laboratory, USA

G.J. Posakony,

Battelle Northwest Laboratories, USA

C.B. Scruby,

Atomic Energy Research Establishment UK

R.L. Thomas,

Wayne State University, USA

B.R. Tittman,

Rockwell International Science Center USA

R.W. Williams,

United Technologies Research Center. USA

S764

$6 / 88$
Research in nondestructive evaluation (NDE) - also known as nondestructive testing (NDT) - has increased dramatically during the past several decades. Requirements for new materials and new applications of familiar materials have emphasized the need for development of new NDE techniques and improved understanding of more mature techniques. Thus, NDE has evolved, of necessity, into a broad, truly interdisciplinary field.

Until now, NDE research papers have appeared scattered throughout a broad spectrum of publications. To provide a single source and medium of exchange for scientific and engineering researchers from diverse disciplines working with NDE, Springer-Verlag, in cooperation with the American Society for Nondestructive Testing (ASNT), will publish Research in Nondestructive Evaluation, an international, peer-reviewed journal.

\section{Aims \& Scope}

Research in Nondestructive Evaluation will publish original research in all areas of NDE. Coverage will include experimental and theoretical investigations into the scientific bases of NDE, its measurement methodology, and its use to evaluate materials and structures that relate to the entire life cycle. Illustrative topics include advances in the underlying science of acoustic, thermal, electrical, magnetic, optical, and ionizing radiation techniques and their application to NDE problems. These problems include nondestructive characterization of a wide variety of material properties and their degradation in service, nonintrusive sensors for monitoring manufacturing and materials processes, new techniques and combinations of techniques for characterizing hidden flaws and distributed damage, standardization concepts, and quantitative approaches for advanced NDE techniques.

Research in Nondestructive Evaluation is now accepting full-length technical articles to be considered for publication. There are no page charges or excess page charges. Four issues per year are planned, the first to appear in early 1989.

For author instructions, or to request a complimentary issue of the journal when it appears, please contact Margo Martin, Springer-Verlag New York, Inc., 175 Fifth Avenue, New York, NY 10010 USA

\section{Springer-Verlag}

New York Berlin Heidelberg Vienna London Paris Tokyo 